\title{
THE INFLUENCE OF ROUGHNESS ON THE DISCHARGE COEFFICIENT OF A BROAD-CRESTED WEIR
}

\author{
JANA PǍ̌íLKOVÁ, JAROMÍR ŘÍHA, ZBYNĚK ZACHOVAL
}

Brno University of Technology, Faculty of Civil Engineering, Institute of Water Structures, Veveři 95, 60200 Brno, Czech Republic; Mailto: riha.j@fce.vutbr.cz, tel.: +420 541147753, fax: +420 541147752

The use of environmentally-friendly materials in hydraulic engineering (e.g. the stone lining of weirs at levees) calls for the more accurate estimation of the discharge coefficient for broad-crested weirs with a rough crest surface. However, in the available literature sources the discharge coefficient of broad-crested weirs is usually expressed for a smooth crest. The authors of this paper have summarized the theoretical knowledge related to the effect of weir crest surface roughness on the discharge coefficient. The method of determination of the head-discharge relation for broad-crested weirs with a rough crest surface is proposed based on known discharge coefficient values for smooth surfaces and on the roughness parameters of the weir. For selected scenarios the theoretical results were compared with experimental research carried out at the Laboratory of Water Management Research, Faculty of Civil Engineering (FCE), Brno University of Technology (BUT).

KEY WORDS: Levee, Broad Crested Weir, Discharge Coefficient, Roughness.

Jana Pařílková, Jaromír Říha, Zbyněk Zachoval: VLIV DRSNOSTI NA VELIKOST SOUČINITELE PRŮTOKU U PŘELIVU SE ŠIROKOU KORUNOU. J. Hydrol. Hydromech., 60, 2012, 2; 32 lit., 13 obr., 2 tab.

Používání přírodě blízkých materiálů ve vodním hospodářství (např. kamenná opevnění povrchu přelivů v ochranných hrázích) vyvolává požadavek přesnějšího stanovení součinitele průtoku pro přelivy se širokou a hydraulicky drsnou korunou. V dostupných literárních pramenech je součinitel průtoku přelivů se širokou korunou obvykle vyjádřen pouze pro hladký povrch koruny přelivu. Autoři článku shrnuli teoretické poznatky týkající se vlivu drsnosti povrchu koruny přelivu na součinitel průtoku a navrhli metodu pro stanovení způsobu hydraulického výpočtu konzumční křivky přepadu přes přeliv se širokou a drsnou korunou. Postup vychází ze znalosti součinitele průtoku přelivu s hladkou korunou a charakteristik drsnosti. Pro vybrané scénáře byly teoreticky vypočítané hodnoty porovnány s výsledky experimentálního výzkumu uskutečněného v Laboratoři vodohospodářského výzkumu Ústavu vodních staveb, Fakulty stavební, Vysokého učení technického v Brně.

KLÍČOVÁ SLOVA: ochranná hráz, přeliv se širokou korunou, součinitel průtoku, drsnost.

\section{Introduction}

Broad crested weirs are frequently utilized in hydrotechnical engineering e.g. as part of weir structures in open channels, as lateral weirs on flood levees or as discharge measuring devices. In hydraulic calculations it is usually assumed that the overflow surface is relatively smooth, e.g. in the case of concrete structures. In such a case the discharge coefficient depends on the shape of the nose of the upstream entrance (sharp with vertical wall, inclined, rounded, etc.) and its value is related to the overflow head.
Lateral spillways at flood levees are special structures. They are specific in their extensive length, which on many occasions may exceed hundred meters, and also in their relatively small overflow head which usually does not exceed $0.50 \mathrm{~m}$. The spillway crest mostly follows the crest of the levee and is usually lined so as to be protected against scouring during its overtopping. The lining very often consists of rip-rap, beaching, stone pitching or gabions with the grain size exceeding $50 \mathrm{~mm}$. Due to this the surface cannot be assumed to be relatively smooth and its roughness becomes an important parameter influencing the discharge 
coefficient. Due to the long spillway crest and relatively small overflow head the error in discharge coefficient may have a considerable influence on the discharge rate calculated to be released to the land side of the levee.

Underestimation of the coefficient leads to underdimensioning of the lateral spillway; overestimating of the coefficient leads to higher levees, which results in a considerable increase in the expenses necessary for their construction due to their extensive length. Therefore, efforts tend to be aimed at the determination of the discharge coefficient as accurately as possible as a function of the parameters mentioned above. In the paper the influence of weir crest roughness on the discharge coefficient is determined theoretically via the friction coefficient and verified with experimentally measured data. The study is focused on unsubmerged broad-crested weirs with an inclined (embankmentshaped) upstream approach face with a slope of $1: 2.5$ and a varying downstream slope of $1: 2$, $1: 3$ and $1: 4$. The weir crest dealt with in this paper was perpendicular to the approaching flow.

\section{Review of the present state}

The hydraulics of broad crested weirs is widely discussed in the worldwide literature. The basic approaches to broad crested weirs with overflow formulas and corresponding discharge coefficients are cited in practically all textbooks on hydraulics and fluid mechanics e.g. (Kiselev, 1972), (Munson et al., 1994) and others. Usually, only general information on discharge coefficients as a function of approach configuration is mentioned.

The hydraulic properties of broad crested weirs are usually expressed by the discharge coefficient characterizing the functional dependence between overflow head and the flow rate.

In the Czech Republic the determination of the discharge coefficient in the context of the design and use of structures which measure or regulate the flow rate in open channels is standardised and bound in national and international standards ( $\check{C} S N$ ISO 3846, 3847, 4362, 4374, 8333). Comprehensive overviews of discharge measurement structures with instructions, standards and procedures for their selection, design and use have been produced by Hager, 1993 and Bos et al., 1989. The topic of flow measurement together with theoretical analysis is presented in manuals such as USBR, 2001, while deeper analyses completed with experimental research have been presented in scientific papers
(Hager and Schwalt, 1994; Fritz and Hager, 1998; Al-Khatib, 2001; Sarker and Rhodes, 2004; Gonzales and Chanson, 2007; Bukreev et al., 2008), which have improved the body of knowledge related to the shape of the free water surface, the velocity and pressure distribution along broad crested weirs, and also to the value of the discharge coefficient. Some authors, e.g. Moss, 1972; Hager and Schwalt, 1994, deal with corner separation at the upstream edge of smooth square-edged broadcrested weirs and with boundary layer phenomena (Hall, 1962; Al-Khatib, 2001). Other authors have analysed special configurations such as broad crested weirs with curved shapes (Khosrojerdi and Kavianpour, 2002) or the compound cross sections (Göğüs et al., 2006; Picek, Havlik, 2008). Flow over oblique weirs was studied in more detail, e.g. by Wols et al. (2006). Villemonte, (1947) shows that the influence of submergence on the overflow is crucial.

Most authors describe weirs as having a smooth surface, and such structures are usually manufactured from concrete; experimental devices can be made from gypsum, plywood plates, fiberglass, plexiglass or other relatively smooth materials (Hager and Schwalt, 1994; Fritz and Hager, 1998; Göğ̈̈s et al., 2006). However, the previous research of the authors of this paper (Paŕilková et al., 2009; Zachoval et al., 2009) has indicated the considerable influence of the roughness of the surface of broad crested weirs on the discharge coefficient in the case of low overflow head, and this has not been taken into account in the above-mentioned studies.

\section{Theoretical considerations}

\subsection{Broad crested weir hydraulics}

The object of our study is a broad-crested weir with an inclined approach sometimes referred as an embankment-shaped weir. Our area of concern is the use of such structures as a diverting overflow device constructed on levees, where the width of the broad crested weir can reach tens or hundreds of meters. Therefore, the effect of side contraction can be neglected and the specific overflow discharge $q$ in $\left[\mathrm{m}^{2} \mathrm{~s}^{-1}\right]$ is considered. As the levee is considerably raised above the surrounding floodplain terrain the tailwater depth behind the levee will not exceed the weir crest and the overflow can be considered as unsubmerged. 
The definition sketch and the configuration of the studied structure are shown in Fig. 1. Based on a review of the literature, broad-crested weirs have to satisfy a condition in terms of relative weir length, which is defined as $H / t$, resp. $h / t$, and whose values are listed in Tab. 1 according to various au- thors. Here, $h$ and $H$ are the overflow head and the total energy head upstream of the weir, respective$1 \mathrm{y} ; t$ is the length of the weir crest in the direction of flow.

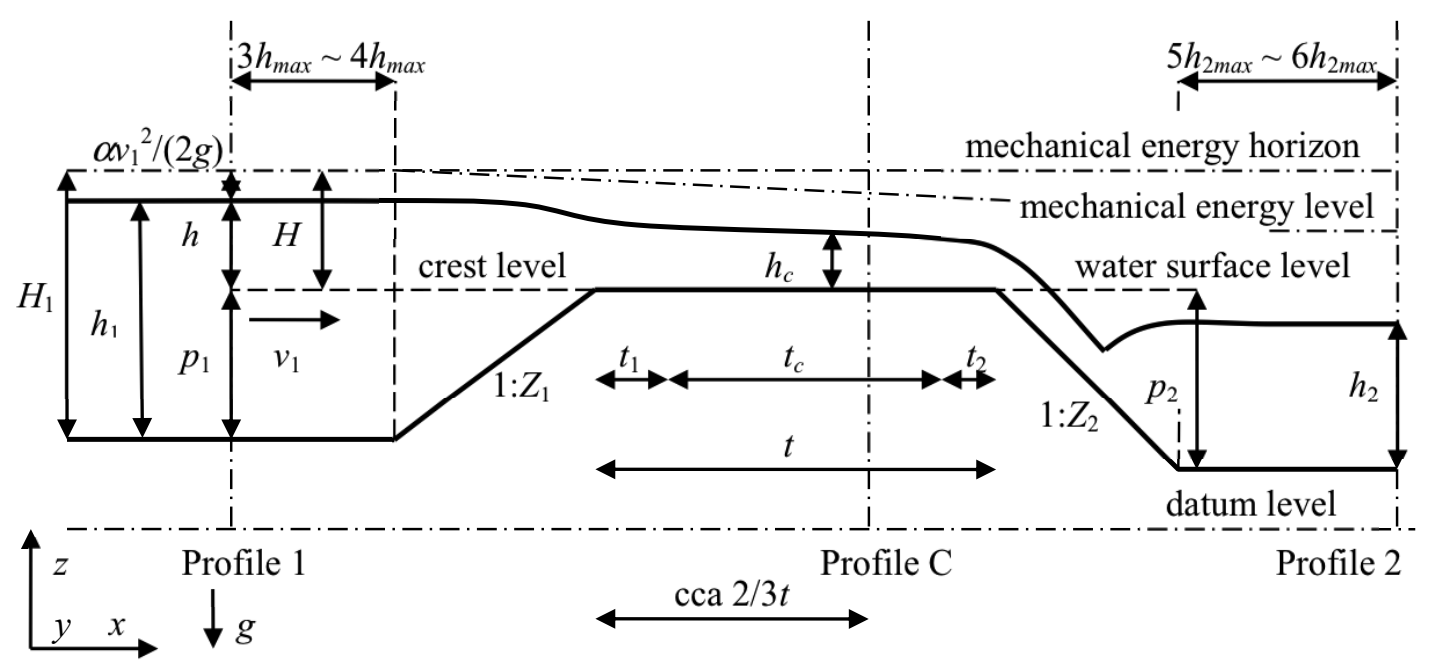

Fig. 1. Conditions at a broad-crested weir.

$\mathrm{T}$ a b 1 e 1. Broad-crested weir limits.

\begin{tabular}{lcc}
\hline Author & $H / t$ & $t / h$ \\
\hline Kolár et al. (1983) & & $(2 \sim 3)<h / t<(10 \sim 15)$ \\
\hline Bos (1989) & $0.07<H / t<0.5$ & \\
\hline Hager, Schwalt (1992) & $0.1<H / t<0.4$ & \\
\hline Clemmens et al. (2001) & & \\
experiments & $0.1<H / t<1.0$ & \\
theory & $0.05<H / t<0.5$ & \\
recommended & $0.07<H / t<0.7$ & \\
\hline
\end{tabular}

The unsubmerged flow at the central part $t_{c}$ of the horizontal crest ( $t_{l} \approx 2 h, t_{2} \approx 0$ to $h$ ) is close to the critical value; the flowlines are approximately parallel and hydrostatic pressure distribution can be considered (Bos, 1989).

In the case that $H / t<0.07$ the friction losses on the weir crest cannot be neglected (Clemmens et al., 2001) and the discharge coefficient is dependent on the relative roughness of the surface.

The discharge equation for the ideal liquid at a broad crested weir can be derived using two energetic approaches. The first assumes the conversion of the mechanical energy in Profile 1 into kinetic energy; while within the second one the mechanical energy is being converted into potential energy and kinetic energy in the critical flow in Profile C (see Fig. 1). In the following text only the second approach is applied.
Considering an ideal flow over a rectangular broad crested weir the discharge $Q_{i}$ is obtained from the following formula $(B o s, 1989)$

$Q_{i}=\left(\frac{2}{3}\right)^{3 / 2} b \mathrm{~g}^{1 / 2} H^{3 / 2}$,

where $b$ is the width of the rectangular broadcrested weir, $\mathrm{g}$ - gravitational acceleration and $H$ is the approach energy head. By introducing the discharge coefficient (taking into account factors according to Eq. (5))

$C_{d}=\frac{Q}{Q_{i}}$,

the discharge equation for real liquid holds: 


$$
Q=C_{d}\left(\frac{2}{3}\right)^{3 / 2} b g^{1 / 2} H^{3 / 2} .
$$

In the case of a high rectangular broad crested weir $(h \approx H)$, the conditions $h / p_{1}<0.15$ and $0.1<h / t<0.3$ have to be fulfilled ( $\check{C} S$ ISO 3846, 1994). Here, $p_{1}$ is the upstream height of the weir. In such cases when the kinetic energy head of the approach can be neglected the discharge coefficient is governed by the following relation:

$$
Q=C_{d}\left(\frac{2}{3}\right)^{3 / 2} b g^{1 / 2} h^{3 / 2},
$$

where $h$ is the overflow head.

\subsection{Discharge coefficient}

The discharge coefficient can be determined using tables, diagrams or functional relations provided by numerous publications or standards including guidance on the estimation of measurement uncertainties ( $\check{C} S N$ ISO 3847, 1997; ČSN ISO 3846, 1994; ČSN ISO 4362, 1995; ČSN ISO 8333, 1997; ČSN ISO 4374, 1997; Bos, 1989; El-Alfy, 2005; Gonzalez and Chanson, 2007; Hulsing, 1986; Khosrojerdi and Kavianpour, 2002), etc. Alternatively, the discharge coefficient can be derived from the results of numerical or experimental modelling (Pařilková et al., 2009; Zachoval et al., 2009).

The discharge coefficient involves mechanical energy losses. Dimensional analysis leads to the following formalised functional dependence of the discharge coefficient on dimensionless geometrical and other parameters:

$$
C_{d}=\mathrm{f}\left\{\frac{h}{p_{1}}, \frac{h}{t}, \frac{h}{b}, \frac{t}{k_{s}}, \frac{h}{k_{s}}, \frac{h}{r}, Z_{1}, Z_{2}\right\},
$$

where $k_{s}$ is the Nikuradse equivalent uniform roughness size, $Z_{1}$ and $Z_{2}$ - upstream and downstream slope factors and $r$ is the radius of the upstream weir nose. In the case of a smooth surface, the dependence (5) simplifies as follows:

$$
C_{d h}=\mathrm{f}\left\{\frac{h_{h}}{p_{1}}, \frac{h_{h}}{t}, \frac{h_{h}}{b}, \frac{h_{h}}{r}, Z_{1}, Z_{2}\right\},
$$

where $C_{d h}$ is the discharge coefficient for a smooth surface and $h_{h}$ is the overflow head in the case of a smooth weir surface.
The meanings of the individual terms in formula (5), resp. (6), are as follows:

$-h / p_{1}$, resp. $h_{h} / p_{1}-$ influence of relative weir head,

- $h / t$, resp. $h_{h} / t$ - influence of relative weir length,

- $h / b$, resp. $h_{h} / b-$ influence of relative weir width,

- $t / k_{s}, h / k_{s}$ - influence of weir roughness,

- $h / r$, resp. $h_{h} / r$ - influence of the roundness of the weir nose,

- $Z_{1}$ - influence of upstream slope inclination,

- $Z_{2}$ - influence of downstream slope inclination,

- influence of approach channel geometry and roughness,

- influence of temperature, surface tension and other factors.

In the following text only the influence of weir roughness, namely the effect of the $h / k_{s}$ ratio, will be studied.

\subsection{Influence of the roughness of the weir surface}

Losses due to friction depend on the flow regime. They differ significantly in cases of laminar or turbulent flow namely for hydraulically smooth surfaces, while for rough surfaces transition range and fully turbulent flow provoke the greatest differences in friction losses. The governing criteria are both the Reynolds number Re and relative roughness $h / k_{s}$. In the case of a change in the flow regime along the weir crest it is necessary to take another factor into account e.g. $t / k_{s}$, which expresses the relative length of the given flow regime.

Generally, the effect of friction at the weir crest surface can be expressed using two methods (USACE, 1992). The first stems from the assumption of uniform flow along the weir crest; Chezy, Manning or Darcy-Weisbach equations can be used. The other method employs the boundary layer theory at the weir crest (Clemmens at al., 2001).

For a given discharge $Q$, due to the weir roughness the overflow head $h$ is larger than that in the case of a smooth weir surface $h_{h}$. The effect of surface roughness is implied in Eq. (4) by introducing the friction head, $h_{f}$, which has to be added to the "smooth" head:

$h=h_{h}+h_{f}$.

The overflow head $h_{h}$ for the smooth weir surface can be taken from the experimental results summarized e.g. in the standards $\check{C} S N$ ISO 3846, 3847, $4362,4374,8333$. 
Weir roughness expressed by the friction coefficient

For the first approach a uniform, fully turbulent and approximately critical flow in a rectangular cross section is assumed. This hypothesis is justified in the case of an approximately critical flow at the weir crest. Assuming the hydraulic radius $R \approx h_{c}$, the friction loss head $h_{f}$ along the weir crest can be expressed as follows (USACE, 1992; García, 2008):

$h_{f}=i_{E} t=\frac{C_{f} t v_{c}^{2}}{h_{c} \mathrm{~g}}=\frac{C_{f} t Q^{2}}{h_{c}^{3} \mathrm{~g} b^{2}}$,

where $i_{E}$ is the energy gradient, $C_{f}$ - the friction coefficient, $v_{c}$ - the critical flow velocity and $h_{c}$ is the critical head with the kinetic energy correction coefficient $\alpha=1$

$h_{c}=\left(\frac{Q^{2}}{\mathrm{~g} b^{2}}\right)^{1 / 3}$.

In the case of steady fully turbulent uniform flow and homogeneous uniform spherical sand grains on the weir surface (Nikuradse's uniform roughness elements), the following resistance law was derived by Keulegan (Garcia, 2008):

$$
C_{f}=\left[\frac{1}{\kappa} \ln \left(11 \frac{h_{c}}{k_{s}}\right)\right]^{-2},
$$

where $\kappa \approx 0.41$ is von Karman's constant. The logarithmic velocity distribution law close to the hydraulically rough wall is applicable only at a distance of about $0.2 h$ from the wall (Garcia , 2008) for large values of the relative roughness $h_{\mathrm{c}} / k_{s}$, the limit of which also depends on the type of roughness (Schlichting, 1979).

For practical calculations the approximation of formula (10) by the Manning-Strickler power form can be used (Garcia , 2008):

$C_{f} \approx\left[8.1\left(\frac{h_{c}}{k_{s}}\right)^{1 / 6}\right]^{-2}$,

which can be applied when the following condition is satisfied:

$$
5<\frac{h_{c}}{k_{s}}<250
$$

Under real conditions the grain shape and grain size significantly differ from being spherical and uniform. The grain size can be expressed by the grain size distribution curve. To express the nonuniformity of the grains the ratio between the Nikuradse equivalent sand roughness size $k_{s}$ of the weir crest and the representative grain size $d_{X}$ of the material at the weir crest is introduced:

$$
\alpha_{s}=\frac{k_{s}}{d_{X}}
$$

where the subscript $X$ means the $X^{\text {th }}$ percentile of a particle-size distribution curve.

The experimentally derived relation between $\alpha_{s}$ and characteristic grain size $d_{X}$ according to various authors (Yen, 2002; García, 2008; Meyer-Peter and Müller (García, 2008)), is recommended to be set at $\alpha_{s}=1$ for $d_{50}$. This assumption is used in further considerations.

\section{The estimate of discharge coefficient $C_{d}$ for rough surfaces}

For practical applications it is desirable to specify the magnitude of the discharge coefficient $C_{d}$ for rough surfaces, respectively to find out its relation to the generally published and used discharge coefficient $C_{d h}$ for smooth surfaces. The latter can be taken e.g. from cited technical standards ( $\check{C} S$ N ISO) or handbooks on fluid mechanics. The method for determining such a relation is as follows:

1. An appropriate set of overflow discharges $Q$ has to be chosen first.

2. Assuming a smooth weir crest, the approach hydraulic head $h_{h}$ is found using an iterative procedure based on the functional relation $C_{d h}\left(h_{h}\right)$ (6) taken from standards, handbooks, etc., and a formula analogical to Eq. (4).

3. For a given discharge $Q$ the following are determined: critical depth $h_{c}(9)$, friction factor $C_{f}$ using Eq. (10) or (11), friction loss head $h_{f}$ along the weir crest from Eq. (8), and finally overflow head $h$ using Eq. (7).

4. By substituting the corresponding discharge $Q$ and the overflow head $h$ into Eq. (4) the discharge coefficient for the rough weir surface $C_{d}$ is obtained.

5. The ratio $\beta$ between the above-mentioned coefficients is defined as follows: 
$\beta=\frac{C_{d}}{C_{d h}}$

(11) is shown in Fig. 2. The application limits of the graphs in Fig. 2 are: $5<h_{c} / k_{s}<30,0.1<h_{h} / t<$ $<0.3, h_{h} / p_{1}<0.7, h_{h}>0.06 \mathrm{~m}$.

The dependence of ratio $\beta$ on the relative roughness $h_{c} / k_{s}$ and $h_{h} / t$ expressed using Eqs. (10) and

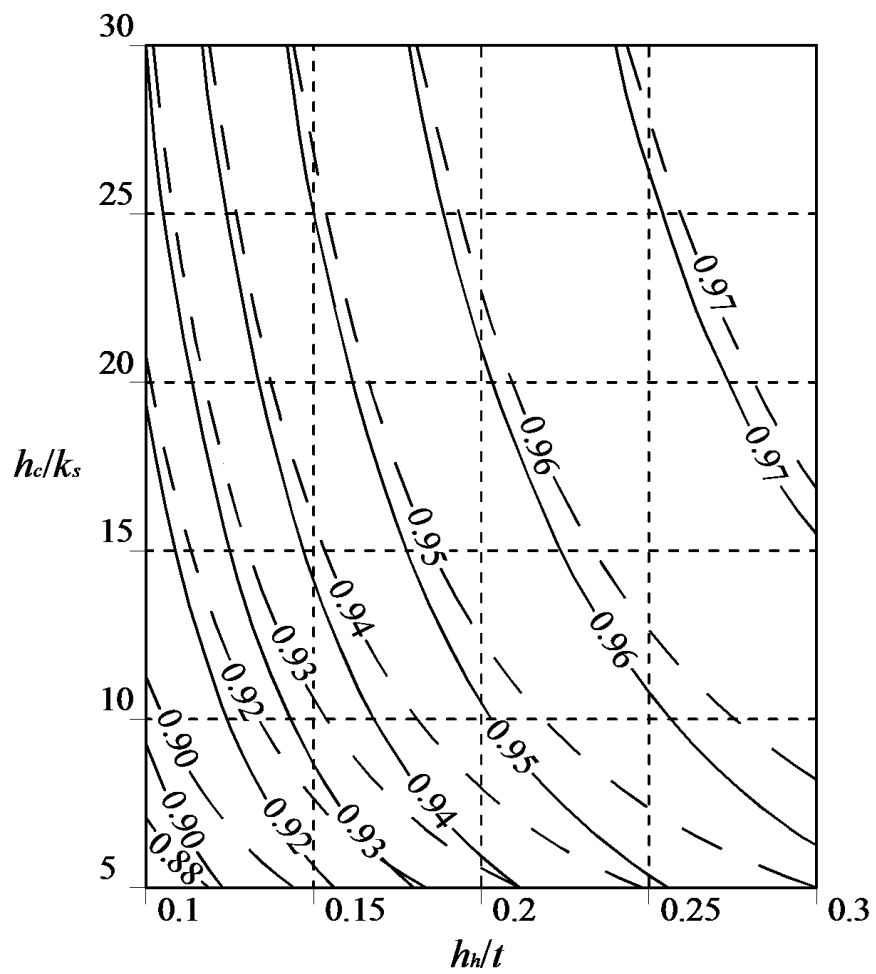

Fig. 2. The ratio $\beta$ as a function of $h_{c} / k_{s}$ and $h_{h} / t$ : the dash-dot line is represented by Eq. (10) and the solid line represents Eq. (11).

From Fig. 2 it can be seen that the ratio $\beta$ approaches a value of 1 with increasing ratios of $h_{c} / k_{s}$ and $h_{h} / t$. When decreasing both non-dimensional ratios the ratio $\beta$ decreases and also the difference between the values obtained using the two approaches represented by Eq. (10) and (11) increases, in particular in the case of smaller $h_{c} / k_{s}$. The diagram in Fig. 2 can be used for obtaining $C_{d}$ as an alternative to the procedure described above.

\section{Experimental research}

The aim of the experimental research was to verify the theoretical considerations mentioned above.

\subsection{Description of the experimental equipment}

The experimental measurements were carried out in a $6 \mathrm{~m}$ long and $1 \mathrm{~m}$ wide flume with a smooth plexiglass vertical wall on one side; the second side wall was made of steel. With respect to the relative- ly small overflow head the effect of the smooth walls was neglected and the flow was considered to be two-dimensional.

The weir shape was designed according to the real conditions at the levee or small embankment dam. The cross section was trapezoidal with an upstream slope of $1: 2.5$ and a variable downstream slope of $1: Z_{2}\left(Z_{2}=2,3,4\right)$ (see the photo in Fig. 4); the weir width was $1 \mathrm{~m}$. The lining was stabilised by a concrete sill installed at the downstream edge of the weir crest (Fig. 3) which also represented the weir crest level: in the case of the rough surface it was very difficult to unambiguously define this level. In the absence of an impervious sill the seepage flow through the gravel lining would have distorted the measured flow discharge over the weir crest.

The crest height above the upstream flume bed $p_{1}=0.46 \mathrm{~m}$; the upstream slope was not covered by a gravel lining in order to represent the relatively smooth grassed surface of the levee slopes. The weir crest was covered by a layer of gravel of vari- 
able grain sizes. During the experiment the tailwater level did not reach the crest surface and therefore did not influence the discharge over the weir.

The discharge entering the flume was measured by a DN 300 electromagnetic flowmeter with a direct digital display. The available discharge range was from $01 \mathrm{~s}^{-1}$ to $1281 \mathrm{~s}^{-1}$. Upstream of the weir a stilling tank of the dimensions $1 \mathrm{~m} \times 1 \mathrm{~m} \times 2 \mathrm{~m}$ was installed.

For a given discharge the water level was measured at a distance of $3 h$ upstream of the weir. The measurement was carried out by plotting the water level on the outer plexiglass wall.

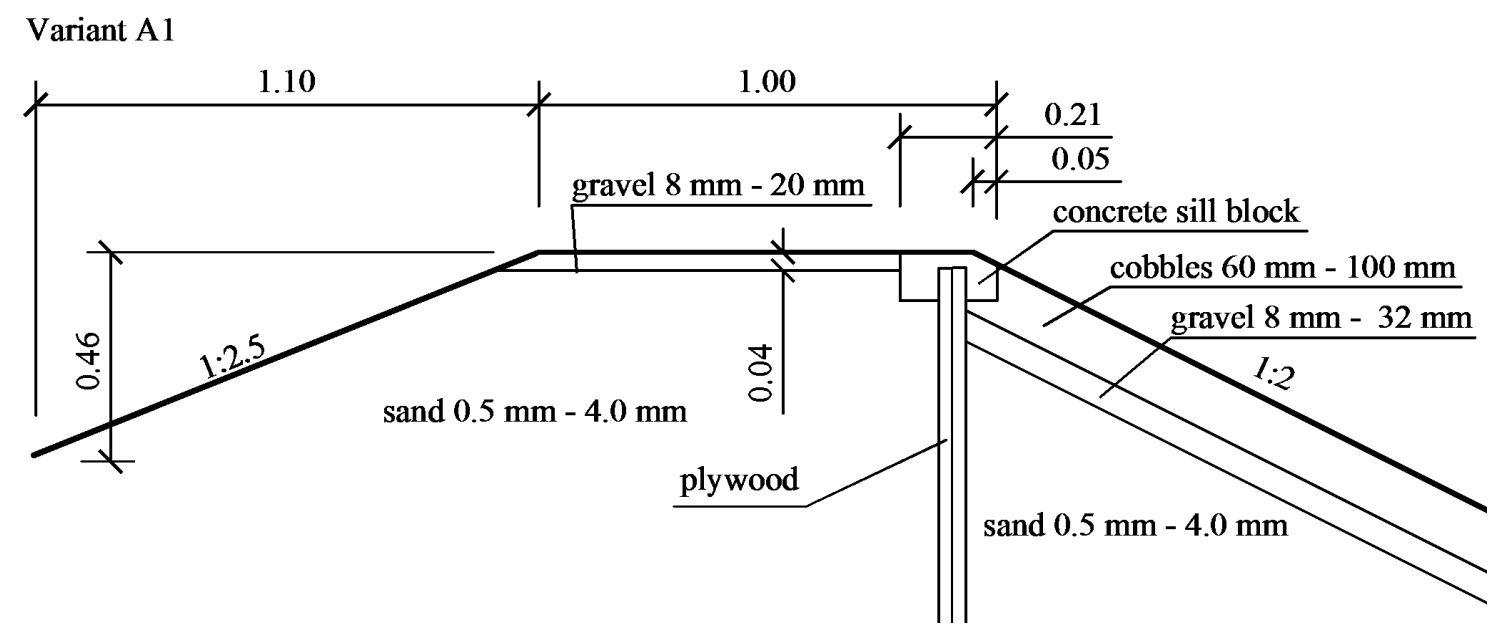

Fig. 3. Scheme of Variant A1 of an experimental dike with a rough crest surface.

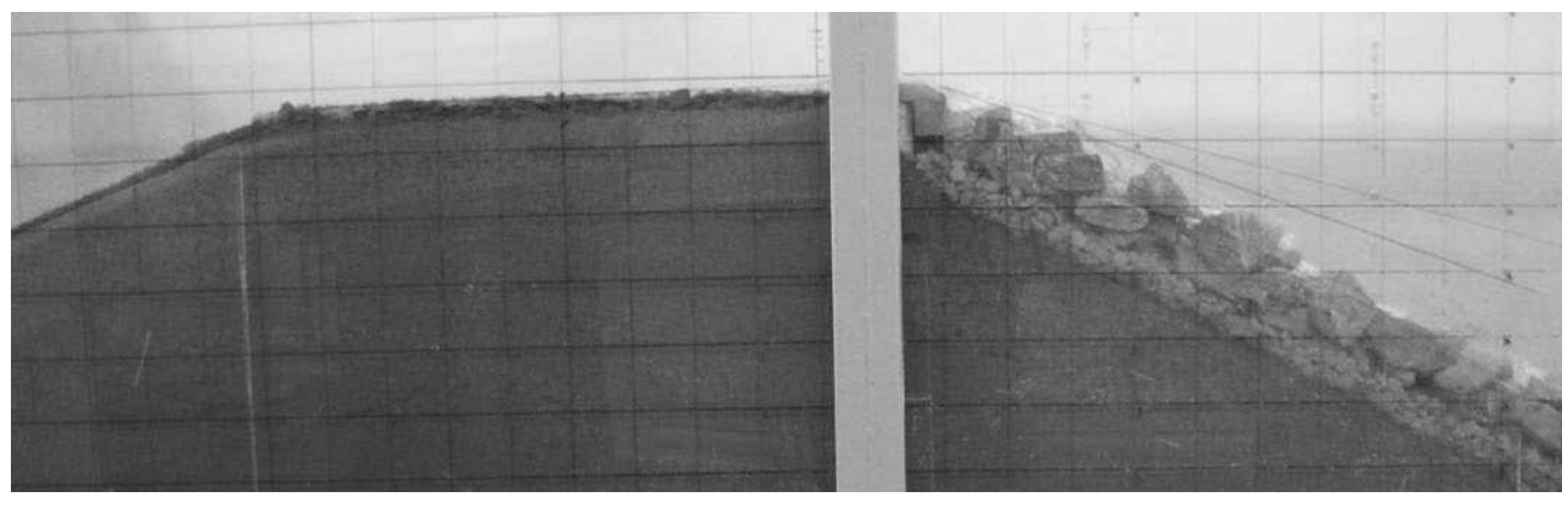

Fig. 4. Photograph of Variant A1 of an experimental dike with a rough crest surface.

\subsection{The experiments}

The experiments were carried out with the material on the surface of the weir exhibiting variable grain size (see Fig. 5) in order to achieve variable roughness of the weir crest. An overview of the parameters of the experiments is shown in Tab. 2. During spreading the material was adjusted to the horizontal plane.

\subsection{Results of experiments}

The weir head-discharge relations were obtained for the individual experiments according to the observed values (Fig. 6). Based on the measured values of $h, Q$ and $b$ the discharge coefficient $C_{d}$ was evaluated from Eq. (4). The influence of the neglected entrance velocity head represents approximately $2 \%$ of the discharge value. The dependence of $C_{d}$ on overflow head $h$ is shown in Fig. 7.

The logarithmic function was used for the approximation of the $C_{d}(h)$ relation based on the experimentally measured values for the variants of different weir crest roughness represented by $k_{s}=d_{50}$ values (Fig. 8). 
T a b l e. 2. Experimental parameters.

$\left.\begin{array}{cccccc}\hline \text { Experiment } & Z_{2} & d_{10} & d_{50} & d_{90} & Q \\ \hline & & {[\mathrm{mm}]} & {[\mathrm{mm}]} & {[\mathrm{mm}]} & {\left[1 \mathrm{~s}^{-1}\right]} \\ \hline \text { A1 } & 2 & 8 & 14 & 20 & 4.9,9.9,15,20,25,30,35,40,45,50,55,60, \\ 70,80\end{array}\right)$
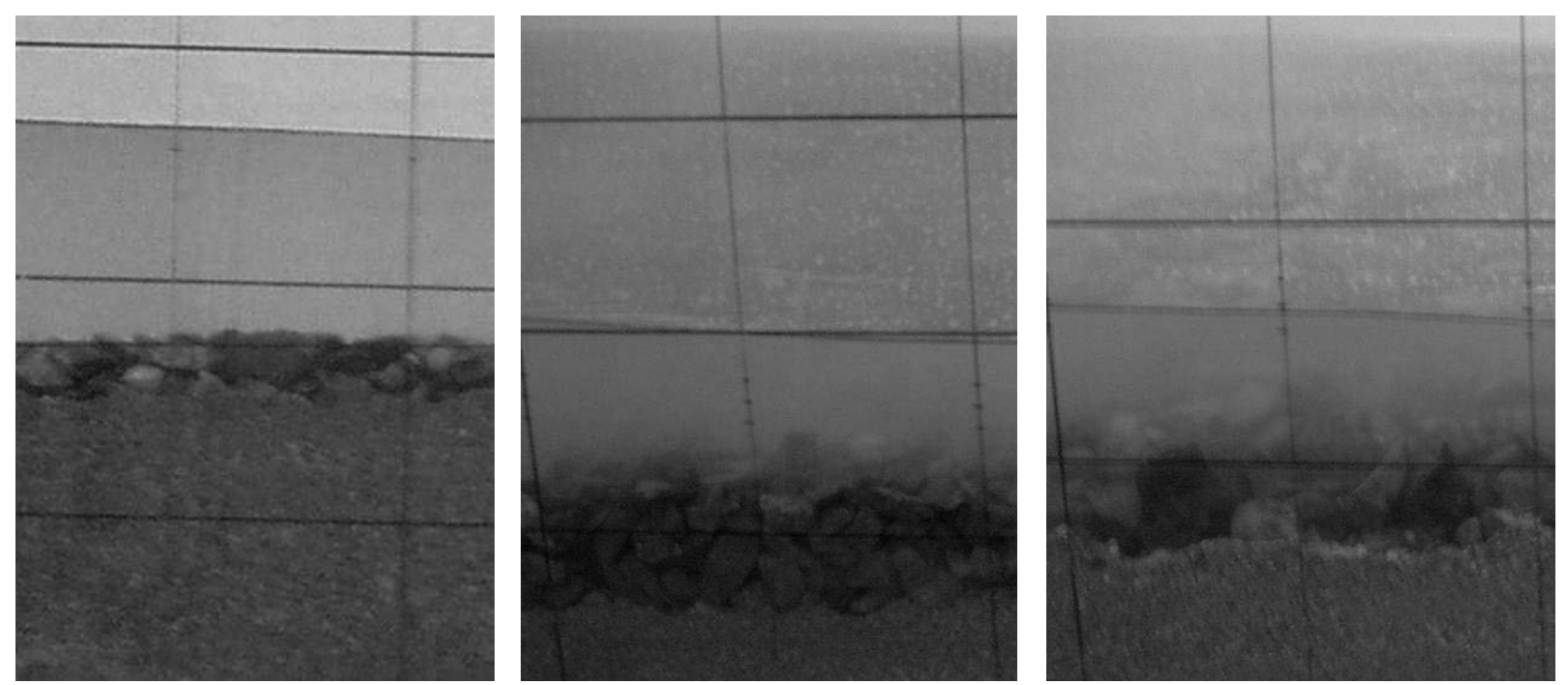

Fig. 5 Material on the weir surface (from the left $d_{50}=14 \mathrm{~mm}, d_{90}=20 \mathrm{~mm} ; d_{50}=20 \mathrm{~mm}, d_{90}=32 \mathrm{~mm} ; d_{50}=24 \mathrm{~mm}$, $d_{90}=40 \mathrm{~mm}$ ).

\section{Comparison of theoretical and experimental results}

Based on the procedure described in section 3.3 the values of the discharge coefficient were calculated for the roughnesses corresponding to the experimental research. The representative grain size was set to $d_{50}$ and the coefficient $\alpha_{s}=1$ (Eq. (13)). The corresponding discharge coefficient $C_{d h}$ for the smooth weir crest surface was taken from the standard ( $\check{C} S N$ ISO 4362, 1995).

The comparison of the relations $C_{d h}(h)$ and $C_{d}(h)$ calculated by the method described in Section 3.3 and the results taken from Fig. 8 is shown in Fig. 9 to Fig. 11. Here, the solid lines denote the logarithmic approximation of the measured values; the dashed lines represent the values calculated by the procedure given in Section 3.3 using Eq. (10) and the dash-and-dot lines depict the relation derived in Section 3.3 using Eq. (11). The range for the fulfilment of condition (12) is also marked out.

The dependence $C_{d}\left(h_{c} / k_{s}\right)$ for the measured data and for theoretical values derived from Eq. (10) and (11) is compared in Fig. 12 and Fig. 13.

The comparison of the results of theoretical analysis and experimental research indicate the following general conclusions:

- The downstream slope $Z_{2}$ of the weir and its roughness have only a negligible effect on the value of the coefficient of discharge $C_{d}$ as compared to the roughness of the spillway crest (Fig. 7).

- Experimental results (Fig. 12 and Fig. 13) prove the theoretical consideration shown in Fig. 2 


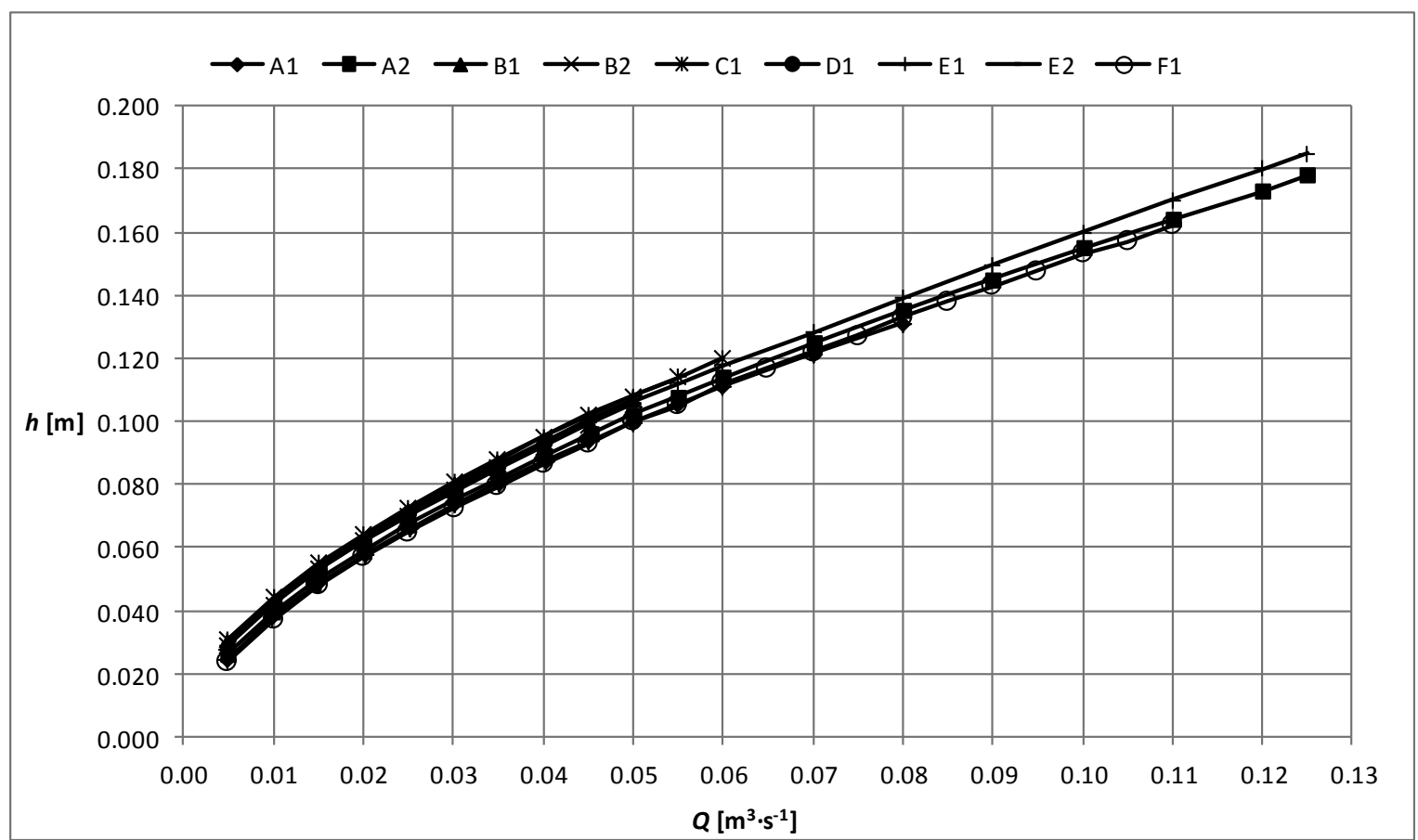

Fig. 6. Experimentally determined head-discharge relations of the weir for individual variants.

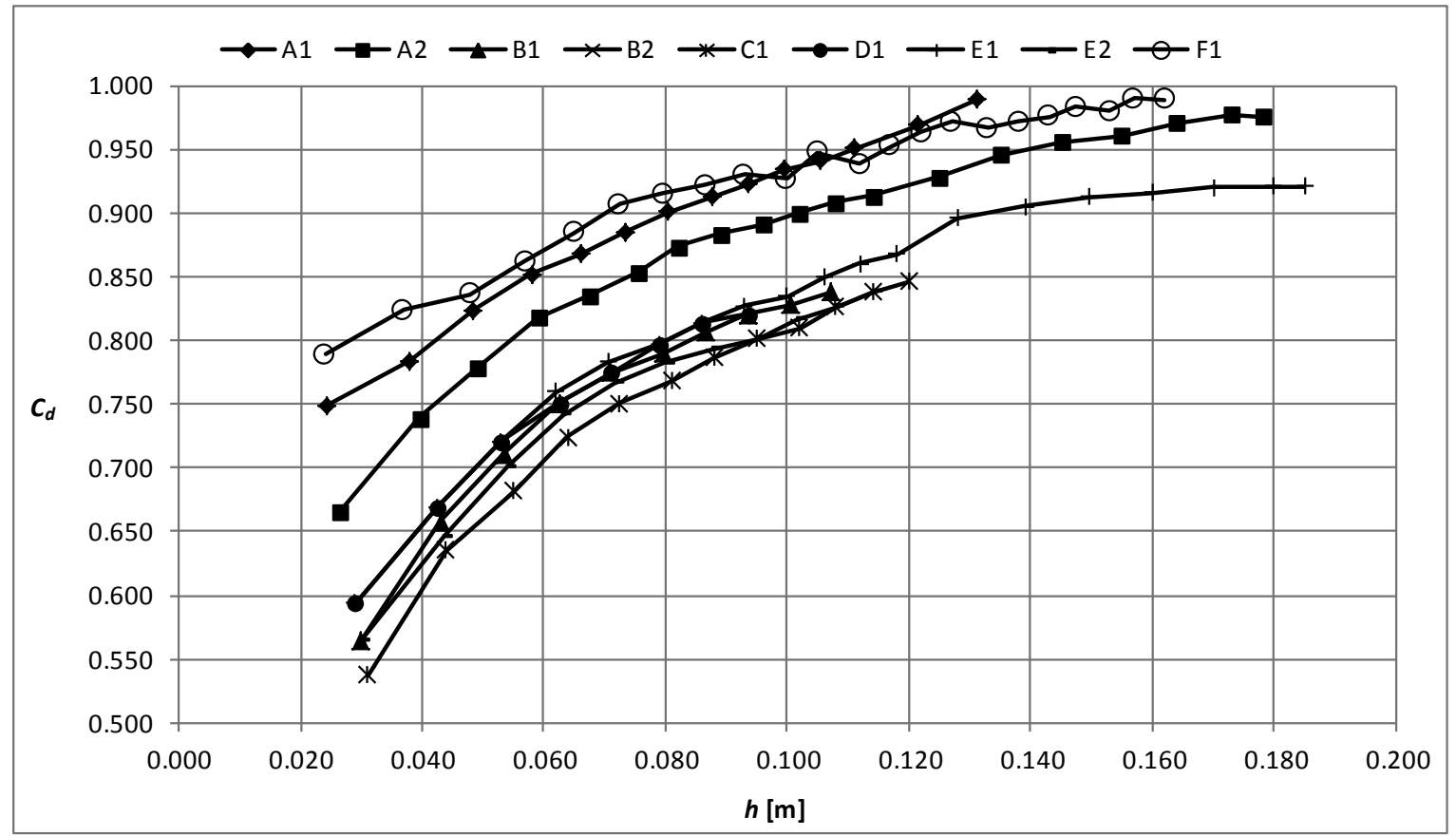

Fig. 7. Discharge coefficient $C_{d}$ related to overflow head $h$ for individual variants. 


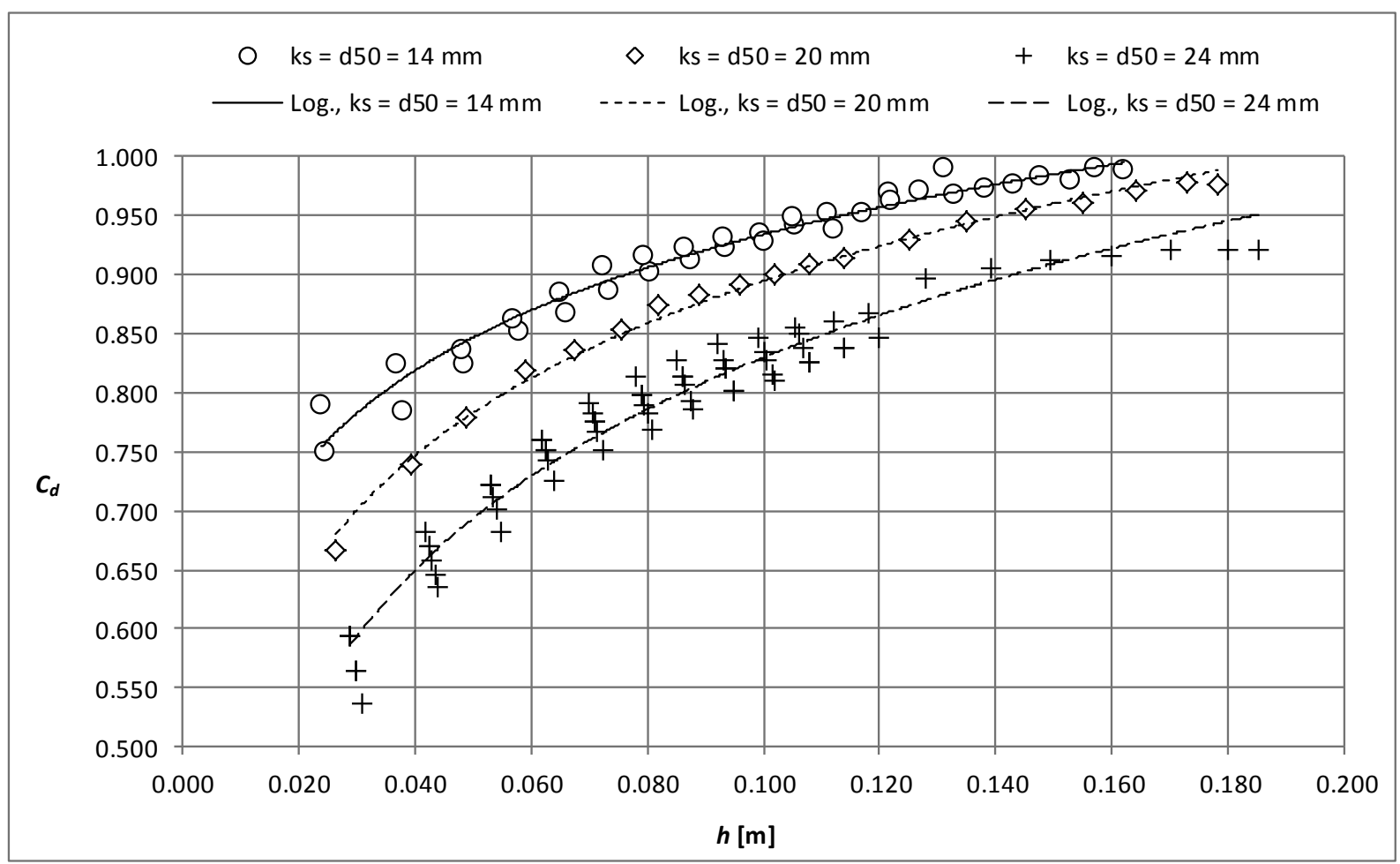

Fig. 8. Approximation of $C_{d}(h)$ related to the grain size $k_{s}=d_{50}$ by a logarithmic function.

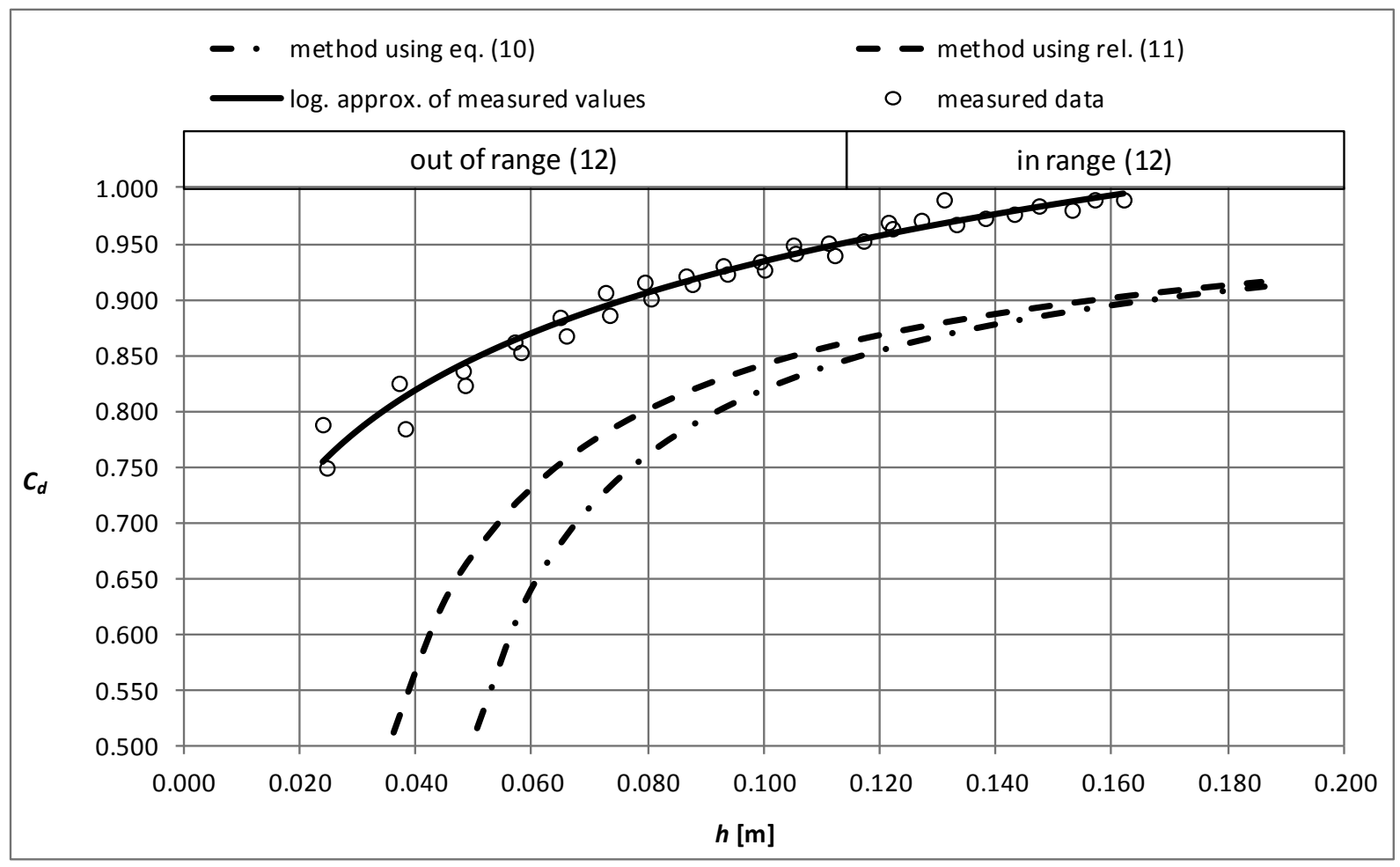

Fig. 9. The dependence $C_{d}(h)$ for $k_{s}=d_{50}=14 \mathrm{~mm}$. 


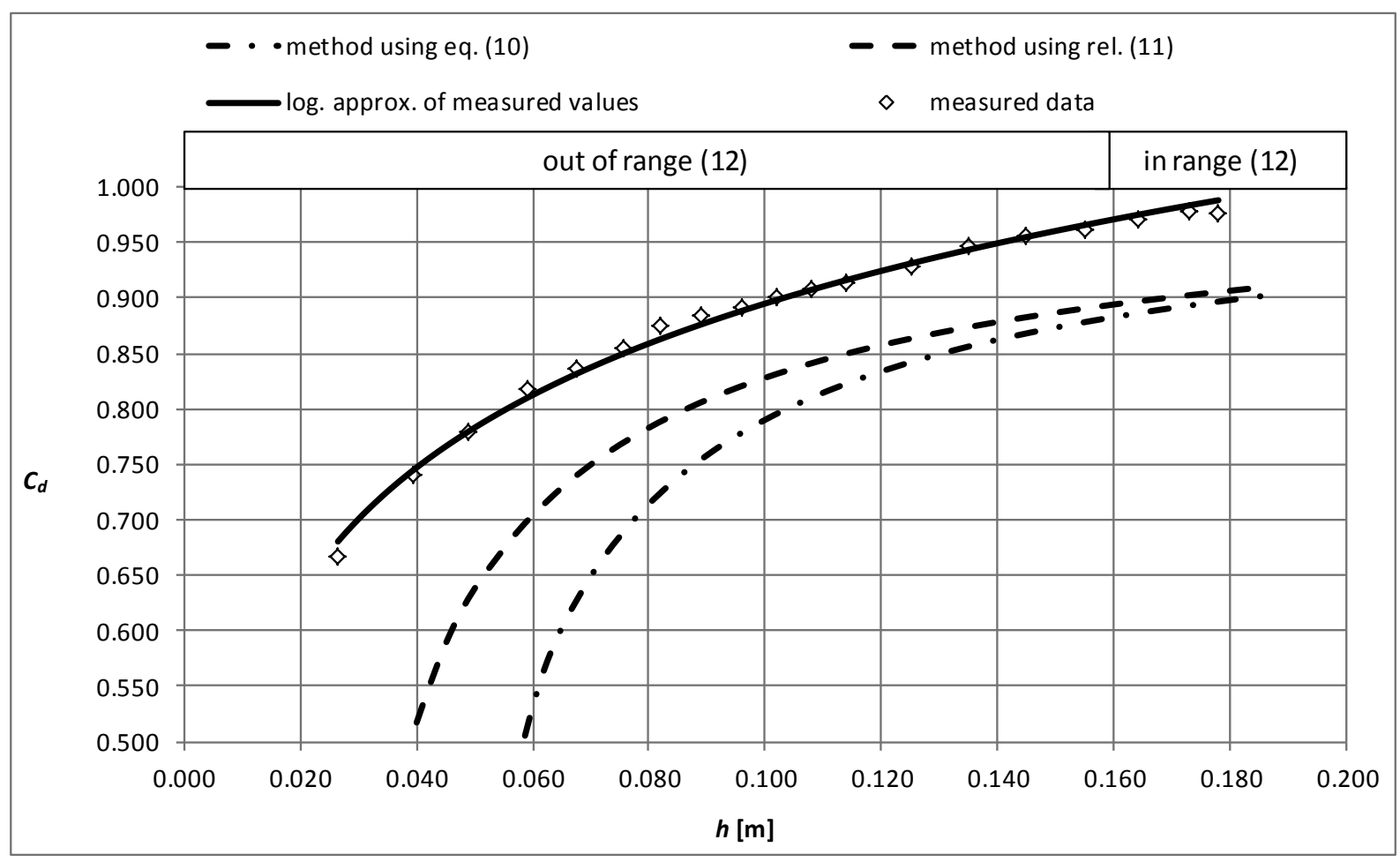

Fig. 10.The dependence $C_{d}(h)$ for $k_{s}=d_{50}=20 \mathrm{~mm}$.

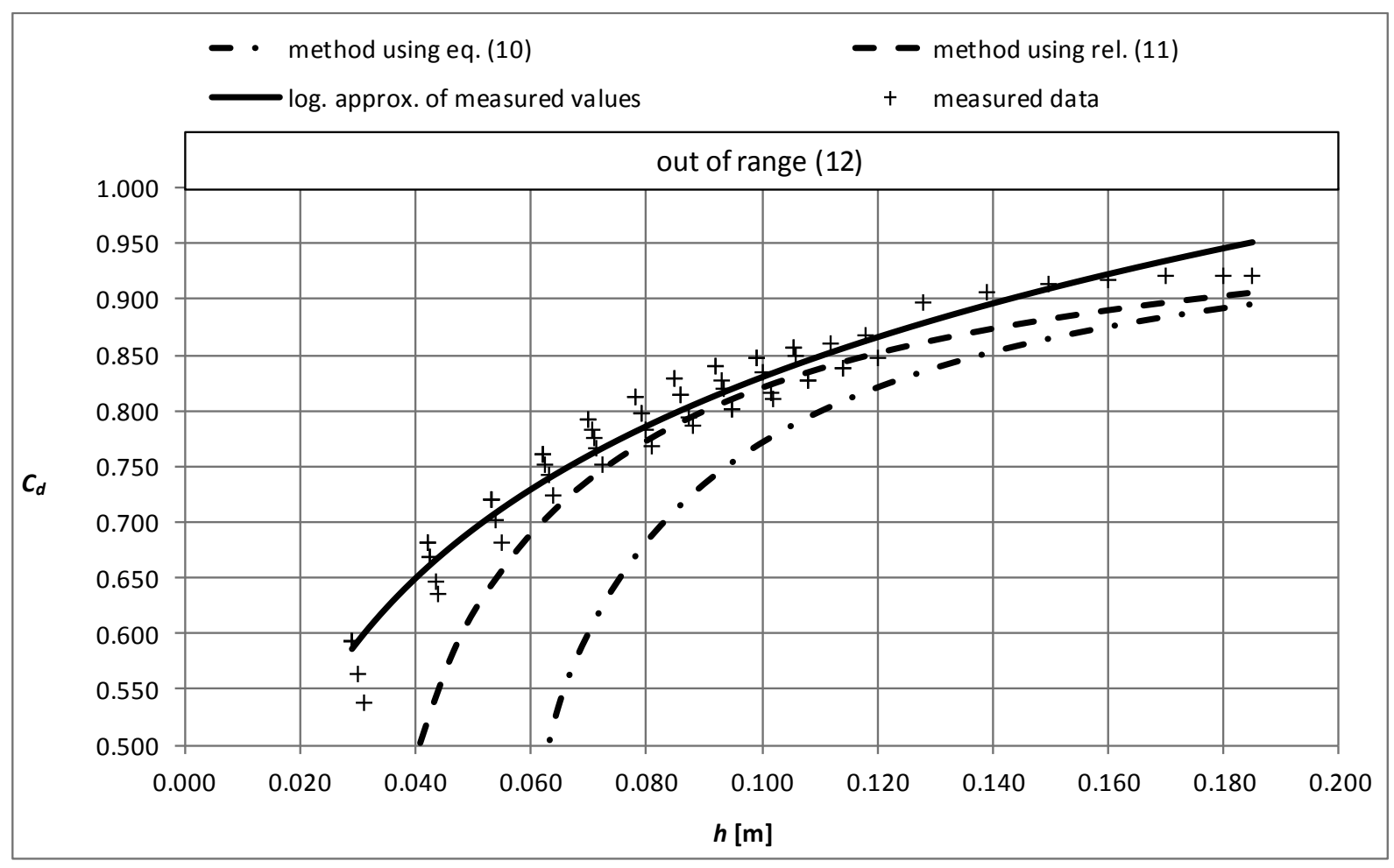

Fig. 11. The dependence $C_{d}(h)$ for $k_{s}=d_{50}=24 \mathrm{~mm}$. 


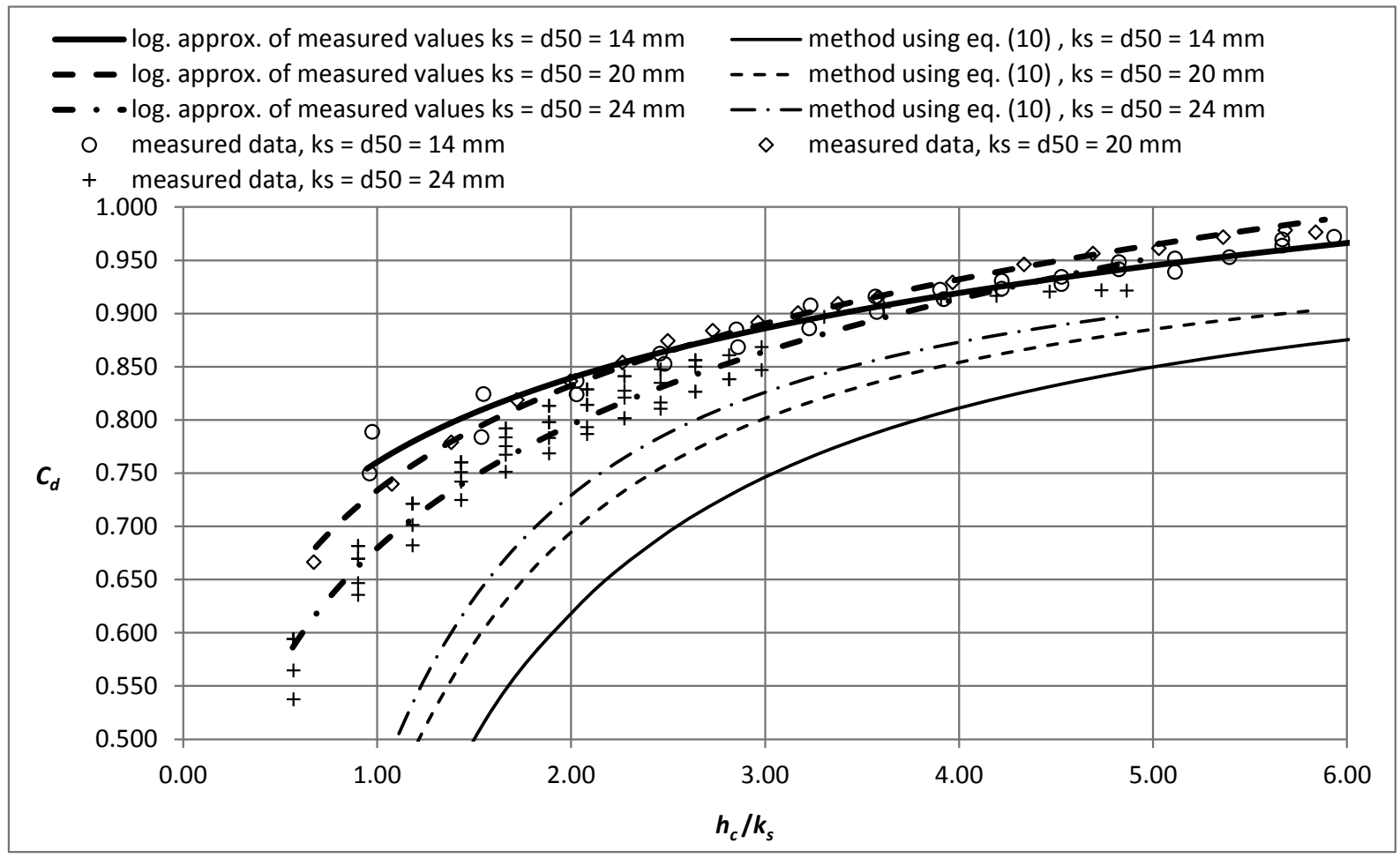

Fig. 12. Dependence $C_{d}\left(h_{\mathrm{c}} / k_{s}\right)$ obtained by the method using Eq. (10).

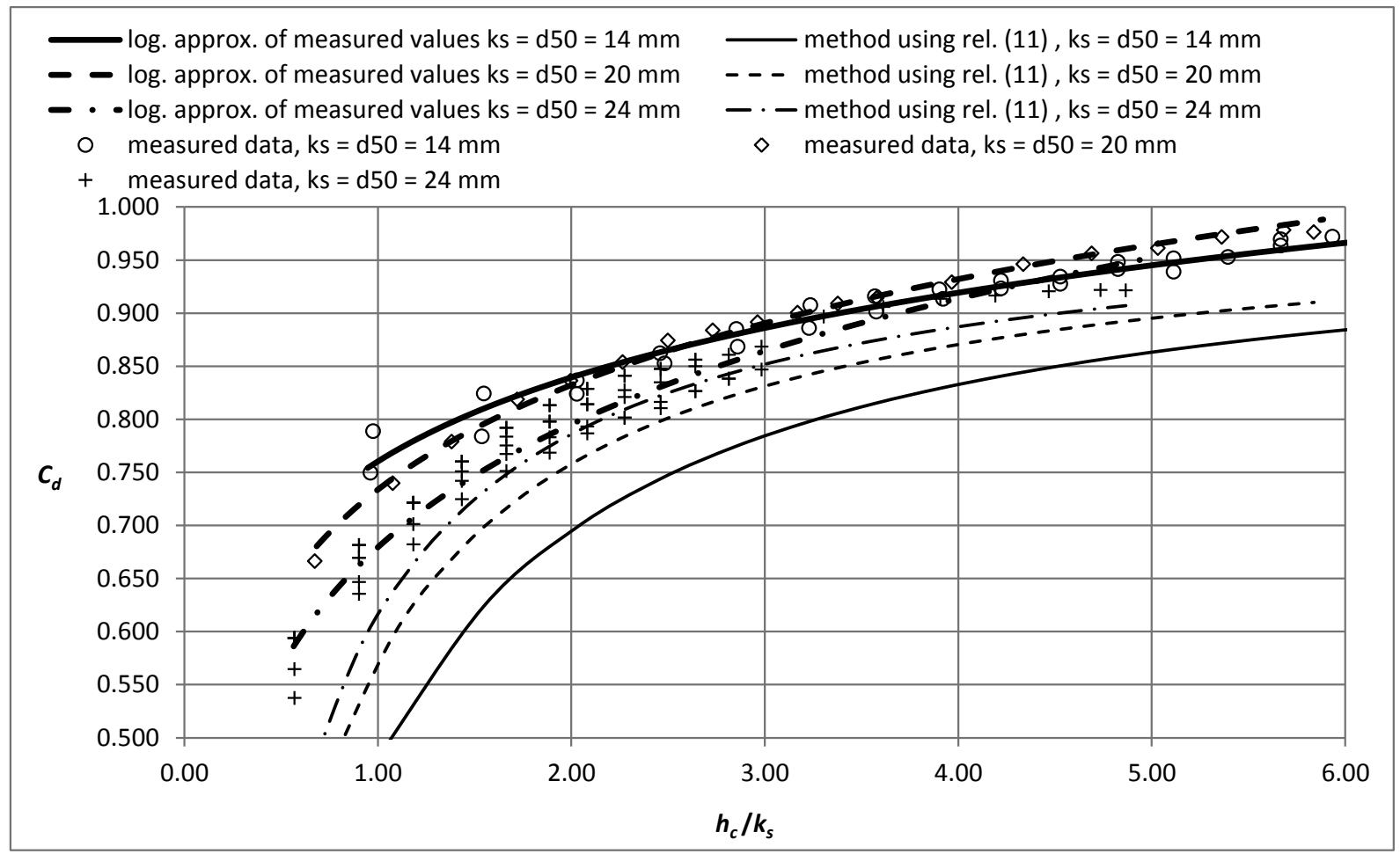

Fig. 13. Dependence $C_{d}\left(h_{\mathrm{c}} / k_{s}\right)$ obtained by the method using relation (11). 
regarding the decrease in discharge coefficient $C_{d}$ with falling relative roughness $h_{c} / k_{s}$. The effect of the relative roughness $h_{c} / k_{s}$ becomes more significant when the values of this ratio are small (Fig. 2).

- The effect of the relative width of the weir $h_{h} / t$ was not evaluated in detail; however, Fig. 2 shows practically the same trend as in the case of relative roughness $h_{c} / k_{s}$.

- From Fig. 9 to Fig. 11 a significant difference can be seen between the values of the discharge coefficient $C_{d}$ obtained from Eqs. (10) and (11) and the experimental values. For $k_{s}=d_{50}=14 \mathrm{~mm}$ the difference is about $10 \%$ within the whole range of $h_{\mathrm{c}} / k_{s}$ values fitting condition (12). For larger grains the differences become smaller. If condition (12) is not satisfied, the differences increase up to about $40 \%$. However, theoretically and experimentally obtained curves are of a similar shape, thus proving the logarithmic resistance law.

- Figs. 12 and 13 show that the effect of the relative roughness on the value of the coefficient $C_{d}$ for $h_{c} / k_{s}<5$ determined by the measurement is smaller compared to the effect determined by calculation using theoretically based procedures (section 3.3). The difference between theoretical and measured values can be also caused by a certain difference between the real discharge coefficient $C_{d h}$ for the experimental device (which was not measured) and that mentioned in ISO standards.

- In cases when condition (12) is satisfied both Eqs. (10) and (11) can be used. In general, when $h_{\mathrm{c}} / k_{s}<5$, Eq. (11) gives better results when compared with experimental research (see also Figs. 9, 10, 11). Based on Fig. 13, Eq. (11) can be recommended for cases when $h_{c} / k_{s}>2$.

\section{Conclusions}

In this paper a theory-based method has been proposed for the estimation of the discharge coefficient $C_{d}$ for the crest of a rough broad crested weir. The results obtained from the proposed procedure were compared with the values obtained from experimental research carried out in the LWMR, FCE, BUT, Brno. The comparison was carried out for two modifications of the resistance law expressed by Eqs. (10) and (11).

The discharge coefficient $C_{d}$ was derived for the trapezoidal cross section of an overflowed structure (e.g. a flood levee). In the analysis only the effect of the crest roughness $\left(t / k_{s}, h / k_{s}\right)$ was studied; the other factors mentioned in Eq. (5) are included in the value of discharge coefficient $C_{d h}$ for a smooth weir crest according to the relation (6). The velocity of approach was neglected.

In our study the values of $C_{d h}$ were not experimentally verified and are assumed to be known from the available literature or standards, e.g. ( $\check{C} S N$ ISO 3846, 3847, 4362, 4374).

It should be noted that only three variants of surface roughness were studied and experimentally verified in 124 tests. For a sound statistical assessment and proper error analysis more extensive research should be done.

Nevertheless, the method proposed has general relevance and can be used for more accurate hydraulic calculations of broad crested weirs with a rough crest.

Acknowledgement. This research was supported by the research projects NAZV QH 81223 and QI 92A139.

\section{REFERENCES}

AL-KHATIB I. A., 2001: Relationship in Flow Measurement Structures of Symmetrical Rectangular Compound Cross Sections. J. Islamic University of Gaza, Vol. 9, no. 2, p. 11-39 .

BOS M. G., 1989: Discharge Measurement Structures, International Institute for Land Reclamation and Improvement/ILRI, Wageningen, The Netherlands.

BUKREEV V. I., DEGTYAREV V. V., 2008: Discharge and Energy-Loss Coefficients In Flow Through a Breach in a Trapezoidal Dam. J. Applied Mechanics and Technical Physics, Vol. 49, No. 1, pp. 53-57.

CLEMMENS A. J., WAHL T. L., BOS M. G., REPLOGLE J. A., 2001: Water Measurement with Flumes and Weirs. International Institute for Land Reclamation and Improvement/ILRI, Wageningen, the Netherlands.

ČSN ISO 3846 (25 9332), 1994: Liquid flow measurement in open channels by weirs and flumes. Rectangular broadcrested weirs.

ČSN ISO 3847 (25 9333), 1997: Measurement of liquid flow in open channels by weirs and flumes. End-depth method for estimation of flow in rectangular channels with a free overfall.

ČSN ISO 4362 (25 9335), 1995: Measurement of liquid flow in open channels. Trapezoidal profile weirs.

ČSN ISO 4374 (25 9337), 1997: Liquid flow measurement in open channels. Round-nose horizontal broad-crested weirs.

ČSN ISO 8333 (25 9339), 1997: Measurement of liquid flow in open channels by weirs and flumes - V-shaped broadcrested weirs.

EL-ALFY K. S., 2005: Effect of Vertical Curvature of Flow at Weir Crest. Ninth International Water Technology Conference, IWTC9, Sharm El-Sheikh, Egypt, pp 249-262. 
FRITZ H. M., HAGER W. H., 1998: Hydraulics of Embankment Weirs. J. Hydraul. Engng., September, Vol. 124, No. 9, pp. 963-971.

GARCÍA M. H., 2008. Sedimentation Engineering. Processes, Measurements, Modeling, and Practice. ASCE Manuals and Reports on Engineering Practice No. 110, ASCE 2008. ISBN 13: 978-0-7844-0814-8.

GÖĞÜŞ M., DEFNE Z., ÖZKANDEMIR V., 2006: BroadCrested Weirs with Rectangular Compound Cross Sections. J. Irrig. Drain. Engng., ASCE, Vol. 132, No. 3, May/June, pp. 272-280.

GONZALEZ C. A., CHANSON H., 2007: Experimental Measurements of Velocity and Pressure Distributions on a Large Broad-Crested Weir, Flow Measurement and Instrumentation, Vol. 18, Issues 3-4, June-August 2007, pp. 107-113 .

HAGER W. H., 1993: Breitkroniger Überfall. Wasser, Energie, Luft.

HAGER W. H., SHWALT M., 1994: Broad-crested Weir. J. Irrig. Drain. Engng., Vol. 120, No. 1, pp. 13-26.

HALL G. W., 1962: Analytical Determination of the Discharge Characteristics of Broadcrested Weirs Using Boundary Layer Theory. Proc.-Inst. Civ. Eng., Vol. 22, Issue 2, pp. $172-190$.

HULSING H., 1968: Measurement of Peak Discharge at Dams by Indirect Method. Application of Hydraulics, Book 3, Chapter A5. USGS, United States Government Printing Office, Washington.

KHOSROJERDI A., KAVIANPOUR M. R., 2002: Hydraulic Behavior of Straight and Curved Broad Crested Weirs, Proc., 5th Int. Conf. on Hydroscience Engineering, IAHR, Warsaw, Poland.

KISELEV P. G., 1972: Handbook on hydraulic calculations. (In Russian.) Energija, Moscow, 312 p.

KOLÁŘ V., PATOČKA C., BÉM J., 1983: Hydraulics. SNTL, Prague 1983.

MOSS W. D., 1972: Flow separation at the upstream edge of a square-edged broad-crested weir. J. Fluid Mech., 52, 2, p. $307-320$.
MUNSON B. R., YOUNG D. F., OKIISHI T. H., 1994: Fundamentals of Fluid Mechanics. 2nd edition, John Wiley, New York, 893 p.

PAŘíLKOVÁ J., PÁNA P., ŘÍHA J., ZACHOVAL Z., 2009: The findings from experimental research into dike spillways. Xii. International Scientific Conference, FCE, BUT, Czech Republic, ISBN 978-80-7204-629-4.

PICEK T., HAVLÍK A., 2008: Calculation of discharge above entirely submerged bridge deck - application of weir equation. J. Hydrol. Hydromech., 56, 2008, 2, 82-87.

SARKER M. A., RHODES D. G., 2004: Calculation of FreeSurface Profile over a Rectangular Broad-Crested Weir, Flow Measurement and Instrumentation, Vol. 15, pp. 215-219 .

SCHLICHTING H., 1979: Boundary-Layer Theory. McGrawHill, Inc. 817 p. ISBN 0-07-055334-3.

USACE, 1992: Hydraulic Design of Spillways - engineer manual. Department of the Army, U.S. Army Corps of Engineers, $170 \mathrm{p}$.

USBR, 2001: Water Measurement Manual. A Water Resources Technical Publication. U. S. Department of the Interior Bureau of Reclamation. 3rd edition, Revised reprint. 485 p. ISBN: 0-16-061763-4

VILLEMONTE J. R., 1947: Submerged weir discharge studies, Engineering news record, Vol. 139, pp. 54-57.

WOLS B., UIJTTEWAAL W., LABEUR R. J., STELLING G., 2006: Rapidly Varying Flow Over Oblique Weirs, the 7th Int. Conf. on Hydroscience and Engineering (ICHE2006), Sep 10-Sep 13, Philadelphia, USA.

YEN B. C., 2002: Open channel flow resistance. J. Hydraul. Engng., ASCE, 128, 20-39.

ZACHOVAL Z., VESELÝ J., PAŘÍLKOVÁ J., 2009: Determination of the discharge coefficient of a trapezoidal broadcrested weir with a rough surface. Symposium of hydro technicians 2009, Brno, Czech Republic. pp. 88-94. ISBN 978-80-214-3883-5.

Received 11 April 2011 Accepted 13 March 2012 